El impacto psicológico de la pandemia de COVID-19 en los atletas de élite, las estrategias de gestión y las expectativas de rendimiento post-pandemia: un estudio de entrevista semiestructurada

\title{
The Psychological Impact of the COVID-19 Pandemic on Elite Athletes, Management Strategies and Post-pandemic Performance Expectations: A Semi-Structured Interview Study
}

Emre Ozan Tingaz.

Gazi University, Faculty of Sport Sciences, Ankara, Turkey. Cag University, Institute of Social Sciences, Mersin, Turkey. emreozan@gazi.edu.tr

\section{RESUMEN.}

Este artículo investiga el impacto psicológico de la pandemia de COVID-19 en los atletas de élite, sus estrategias de manejo y sus expectativas de rendimiento post pandemia. Basado en una técnica de muestreo intencional y bola de nieve, 18 atletas de élite fueron entrevistados en línea. El cuestionamiento involucró sus pensamientos, emociones y comportamiento en el período de la pandemia. La mayoría de los atletas tienen inquietudes con respecto al futuro (31.5\%) y han aumentado su autoconciencia $(26.3 \%)$. No obstante, el $40 \%$ de los atletas han estado luchando contra la ansiedad, con el $40.47 \%$ de ellos haciendo entrenamiento físico en casa, mientras que el $33.33 \%$ realiza entrenamiento mental. Además, el $72.22 \%$ de los atletas esperan un desempeño atlético post pandemia más bajo. En consecuencia, la mayoría de los atletas de élite han estado sufriendo ansiedad como resultado de la preocupación por la situación actual y el rendimiento posterior a la situación y el entorno deportivo de entonces. En general, han podido manejar la situación haciendo entrenamiento físico y mental en casa. La mayoría anticipa una disminución en el rendimiento atlético después de regresar al campo.

\section{PALABRAS CLAVE.}

COVID-19, Atleta de élite, pandemia, expectativas de rendimiento post-pandemia, impacto psicológico, deportes.

\section{ABSTRACT.} This article investigates the psychological impact of the COVID-19 pandemic on elite athletes, their management strategies, and their post-pandemic performance expectations. Based on a purposive and snowball sampling technique, 18 elite athletes were interviewed online. The questioning involved their thoughts, emotions, and behavior in the pandemic period. Most athletes have concerns regarding the future $(31.5 \%)$ and have increased self-awareness (26.3\%). $40 \%$ of athletes have nonetheless been struggling with anxiety, with $40.47 \%$ of them doing physical training at home, while $33.33 \%$ engage in mental training. In addition, $72.22 \%$ of athletes expect poorer post-pandemic athletic performance. Most elite athletes have accordingly been suffering anxiety as a result of worry about both the current situation and

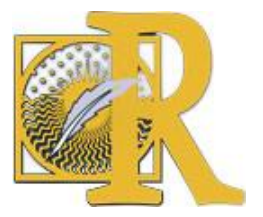


post-situation performance and the sports environment then. By and large, they have been able to manage the situation by doing physical and mental training at home. Most anticipate diminished athletic performance after they return to the field.

\section{KEY WORDS.}

COVID-19, elite athlete, pandemic, post-pandemic performance expectations, psychological impact, Sports.

\section{Introduction.}

The novel COronaVIrus Disease-2019 (COVID-19) is thought to have originated in Wuhan, China, and has now spread to most countries, causing acute infectious pneumonia. Panic and stress are widespread, and worry about being infected has increased with the novel corona virus COVID-19. The ambiguous nature of the epidemic, the lack of good information about the subject, and the misinterpretation of what information is available have dramatically increased worry among many people (Bao, Sun, Meng, Shi \& Lu, 2020). The Republic of Turkey Ministry of Health has been attempting to provide reliable information about the pandemic to both health professionals and the general population. In addition, psycho-social support lines have been created, taking into account the psychosocial effects of the outbreak (Republic of Turkey Ministry of Health, 2020).

One important group affected by the outbreak are athletes. The effect is not only physical but also psychological. Competitions have been postponed or cancelled, and have been replaced by uncertainty (Republic of Turkey Ministry of Youth and Sports). Loneliness, despair, insomnia, depression, and anxiety can occur when such uncertainty increases, and physical isolation can have a psychological effect on athletes and on their post-epidemic sports performance. Previous findings have suggested that athletes with high psychological wellbeing are better at coping styles related to their sports performance (Ridnour \& Hammermeister, 2008). According to the individual optimal functioning zone (IZOF) theory, non-optimal emotions of athletes affect their performance (Hanin, 2007). Many studies examine the relationship between insomnia and athletic performance (Fullagar et al., 2015). Changes in athletes' routines can be seen as one of the most significant effects of the pandemic. Athletes' motivation is affected by decreased training, increased uncertainty in determining goals, and deterioration of routines. This lack of motivation might also have a negative effect on sports performance after the epidemic. A significant relationship between amotivation and athletic performance is also known to exist (Chantal, Guay, DobrevaMartinova \& Vallerand, 1996).

Stress occurs when circumstances exceed perceived coping skills (Palmer \& Cooper, 2013) and when the new situation becomes a daily routine (Pierceall \& Keim, 2007). Coping is defined as a constantly changing cognitive and behavioral effort to manage external and/or internal demands that appear difficult or seem to exceed one's resources (Lazarus \& Folkman, 1984). The coping effort involves two functions, problem-focused and emotion-focused. Problem-focused coping represents the regulation or change of one's relationship to the environment, while emotion-focused coping represents the regulation of stressful emotions (Folkman \& Lazarus, 1980).

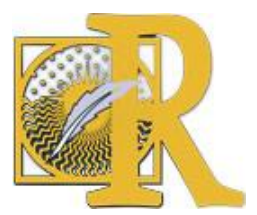

Fecha de recepción: 09-06-2020 Fecha de aceptación: 14-06-2020 
The COVID-19 epidemic can be regarded as a stressor, and athletes respond differently to this stressor. The stress response is at the center of a traumatic experience, and trauma is a physical and mental experience in response to a major stress situation. Traumatic experiences are generally unexpected and uncontrollable events which cause people to feel unprepared and unable to protect themselves (Akhtar, 2017).

In this sense, the COVID-19 pandemic can be understood as a traumatic experience for athletes. Although post-traumatic stress is normal following a traumatic experience (Akhtar, 2017), it may pose a danger to athletes when they return to daily life after the epidemic. The effect of the outbreak on athletes might be continue after the outbreak. This study aims to examine the effect of the COVID-19 pandemic on elite athletes, how athletes manage this process, and performance expectations regarding return to competition. It should shed light on future studies.

\section{Method.}

\section{Participants and Interviews.}

Elite athletes in different provinces of Turkey were included in the study based on a purposive and snowball sampling technique. Sport branches included basketball, volleyball, kickbox, taekwondo, ice hockey, bocce and karate, with a total of 18 athletes, 12 of them women, 6 of them men, and a mean age of 24.44. One of the important criteria of being elite athletes as those competing at international and/or national level (Swann, Moran \& Piggott, 2015). All the participants are international and/or national level athletes most of whom are with success at major international competitions such as World Championships.

A qualitative study using semi-structured interviews was conducted through tape-recording with elite athletes (Crabtree \& Miller, 1999). The interviews were carried out online and lasted about 25-30 minutes. The questions were deliberately open-ended. The main themes were categorized as thoughts, emotions, management strategies, and performance expectations. The main questions were;

Q1: What does the COVID-19 pandemic make you think about?

Q2: What are the most intense feelings you are experiencing during the COVID-19 pandemic?

Q3: How do you manage this situation?

Q4: How do you think your performance will be affected by this situation after you return to competition?

\section{Analysis.}

All interviews were audiotaped, with permission, and transcribed verbatim. Attempts to identify the most common approaches were made by identifying and defining themes or patterns through the systematic classification process of qualitative content analysis and text data, which investigates key themes in analyzed materials (Bryman, 2015; Hsieh \& Shannon, 2005). Before the statements of the participants were written down, each participant was given the codes that continued as from A1 to A18. The statements of each participant in the article were read many times, and the codes were extracted. The coding is intended to provide the foundation for the next step (Auerbach \& Silverstein, 2003). The frequencies of these codes

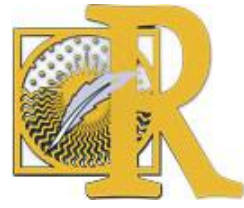


are shown in Table 1 as focus points. Themes were created by considering common points that emerged in the direction of expressions.

Findings. Table 1. Focus points and themes

\begin{tabular}{|c|c|c|c|}
\hline Themes & Focus Points & $\mathbf{f}$ & $\%$ \\
\hline \multirow{5}{*}{ Thoughts } & Thoughts about the future & 12 & 31.5 \\
\hline & Self-awareness & 10 & 26.3 \\
\hline & Value awareness & 9 & 23.6 \\
\hline & Thoughts about the past & 7 & 18.4 \\
\hline & Total & 38 & 100 \\
\hline \multirow{10}{*}{ Emotions } & Anxiety & 12 & 40 \\
\hline & Anger & 4 & 13.3 \\
\hline & Longing & 4 & 13.3 \\
\hline & Depression & 3 & 10 \\
\hline & Sadness & 2 & 6.66 \\
\hline & Stress & 2 & 6.66 \\
\hline & Confidence & 1 & 3.33 \\
\hline & Loneliness & 1 & 3.33 \\
\hline & Fear & 1 & 3.33 \\
\hline & Total & 30 & 100 \\
\hline \multirow{5}{*}{ Management Strategies } & Physical Training & 17 & 40.47 \\
\hline & Mental Training & 14 & 33.33 \\
\hline & Take up a hobby & 7 & 16.66 \\
\hline & Trainer support & 4 & 9.52 \\
\hline & Total & 42 & 100 \\
\hline \multirow{4}{*}{ Performance Expectations } & Decreased & 13 & 72.22 \\
\hline & Constant & 3 & 16.66 \\
\hline & Increased & 2 & 11.11 \\
\hline & Total & 18 & 100 \\
\hline
\end{tabular}

Focus points and themes were created with the expressions of the athletes. There are four themes in total, incorporating 20 focus points. The theme with the most focus points is Emotions, with nine focus points. Thoughts, and Management Strategies follow. In the final theme, Performance Expectation, there are three focus points.

The most frequently expressed focus in the theme Thoughts are Thoughts about the future ( $f$ $=12)$, Self-awareness $(f=10)$, Value awareness $(f=9)$ and Thoughts about the past $(f=7)$. In the theme Emotions, the most frequently expressed focal points are Anxiety $(f=12)$, Anger $(f=4)$, Longing $(f=4)$, Depression (3), Sadness $(f=2)$, Stress $(f=2)$, Confidence $(f=1)$, Loneliness (1) and Fear $(f=1)$. The most frequently expressed focus points in the theme

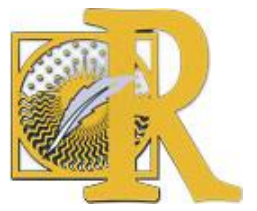


Management Strategies are Physical training $(f=17)$, Mental training $(f=14)$, Take up a hobby $(f=7)$ and Trainer support $(f=4)$. The most frequently expressed focal points in Performance Expectation, the final theme, are Decreased $(f=13)$, Constant $(f=3)$ and Increased $(f=2)$.

\section{Discussion.}

The purpose of this study is to examine how elite athletes are affected psychologically by the COVID-19 pandemic, how they manage the situation, and their expectations for their athletic performance after the outbreak. Accordingly, questions about the thoughts, emotions, strategies for managing the situation, and post-epidemic performance expectations of the athletes were examined through a semi-structured interview. The findings obtained suggest that the most common thoughts that pass through the athletes' minds concern the future. As Oettingen and Mayer (2002) note, thoughts about the future can include beliefs or judgments, or may be free thoughts. It is thought that the process of achieving a goal rather than achievement of the goal itself reduces anxiety and improves performance (Taylor, Pham, Rivkin \& Armor, 1998). It is unsurprising that the most common emotion at this point is anxiety. Thoughts about the future are mostly aimed at coping with uncertainty. Questions about the character of the sports environment after the epidemic are the main concern among athletes who are curious about their performance and the general situation.

Frequently expressed thoughts also often involve self-awareness. Athletes stated that they were alone and had begun to discover aspects of themselves they did not know. In the related literature, self-awareness is significantly positively correlated with mindfulness, well-being, and the importance of self-care (Richards, K., Campenni \& Muse-Burke, 2010). At this point, the positive effect of self-awareness for athletes should be mentioned. Athletes also frequently mention value awareness. The athletes mentioned that they had the opportunity to spend more time with their families in this period, and that they understood the power of nature and the importance of helping others better. Thoughts about the past are among the relatively less expressed forms of thought. Here the athletes stated that their minds were busy with past events. The statements of some athletes are given below.

A3: "I hear different bird sounds every time I open the window. I saw that nature is recovering. I wanted to buy a car, but it sounded very selfish. I realized that endless consumption is unreasonable. This process helped me gain a realistic perspective. Solidarity reminded me not to pollute the natural environment. Maybe people can act more consciously from now on. I worry whether this process is over or not".

A6: "I had the opportunity to confront myself and study. It was mentally better to step into the future. I started to think about the past and the future. I thought "I wish I had done this". I saw what it would be like to stay at home. I couldn't do these things because of my busy sports life. I used this situation to improve. Now I can proceed in a more purposeful way. I couldn't find the right workout, now I found it. I'm more mentally prepared. I turned the crisis into an advantage. I found time for myself. It will be better from now on".

A2: "The facilities are very limited. I try to equip myself academically. I am acquiring the knowledge to deal with anxiety. I think this can help. A move I made in the match comes suddenly alive in my mind. I wish I did it like that. I'm returning there in my mind".

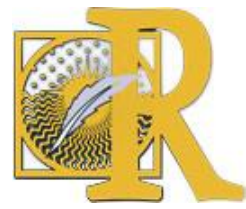


Athletes felt various emotions, but anxiety is the most common. This anxiety seems to be a result of worry about both the current situation and post-situation performance and the sports environment then. While there is a statistically significant relationship between anxiety, depression, and functional somatic symptoms (Haug, Mykletun \& Dahl, 2004), there is a significant negative relationship between anxiety, attentional control (Shi, Sharpe \& Abbott, 2019) and self esteem (Pu, Hou \& Ma, 2017). In this light, the result of the inability of athletes to effectively manage their anxiety is important. Anger and longing are among the most common feelings. Athletes stated that they could not make good use of opportunities in the past, they felt anger due to the postponement or cancellation of competitions, and they missed the sports venue, their friends and their old lives. $10 \%$ of the athletes suffer depression. This problem emerged again in response to the pandemic. Although sadness, stress, loneliness and fear are the least commonly reported emotions, they presumably affect both the athletes' motivation and their post-sport performances. One athlete expressed confidence, saying that he had acquired this as an effect of being at home and getting back to himself. Below are the statements of some athletes about their mood.

A9: "I miss the competition. I miss singing our anthem again, waving our flag, and the power of Turkish people. This situation did not pose much difficulty for me, because I believe in the power of the Turkish people".

A17: "There is great uncertainty. Will there be matches or not? I am very worried about how things will be organized when it starts".

A15: "The most intense feeling in this process is fear. That the virus might infect me or my family scares me so much".

Examination of how the athletes manage the pandemic situation shows that they often engage in physical and mental training. They all mentioned that they do physical training in a home environment, but options are limited. Athletes see mental training as helpful. They watched competitions, followed their competitors, and developed strategies. Indeed, it is has been found that mental training is effective with problems related to specific performance problems (Mamassis \& Doganis, 2004). Athletes began to do things that they wanted to do before but could not, and mentioned that they had acquired new occupations. Some athletes stated that they received support from coaches for physical training during this period. Below are sample statements about how athletes manage the pandemic situation.

A7: "I tried to change my interests. I train mentally. I watched the performance of my competitors and developed tactics. My opponents created YouTube channels, where they showed their training. I didn't do this. I know my opponents' negatives, since visuality prevails in our branch. I have developed tactics against it. This impressed me a lot. I think more positively about future competitions. I am studying. I started writing books".

A5: "My normal routine was very intense. I couldn't spare time for home. I started to take time for myself. I was devoted to sports, there was nothing but sports in my life. I saw that I could

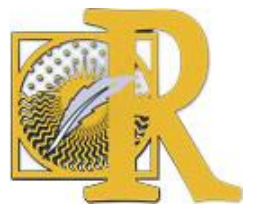

Fecha de recepción: 09-06-2020 Fecha de aceptación: 14-06-2020 
spare more time for myself and my family. I wanted to play an instrument before. I started doing this. I'm trying to learn".

A8:" We made a written plan to manage the process. We are doing mental training, physical training, and Pilates, we are training together with other friends as if we were in camp".

When athletes were asked about their performance expectations after returning to competition after the pandemic, they often emphasized that they expect their performance to decrease. Considering that anxiety is a predictor of performance expectation in athletes (Alexander \& Krane, 1996), it is unsurprising that expectations about performance are negative. A few athletes, however, believe that their performance will remain stable, while a an even smaller group think it will improve. Athletes who stated that their performance levels will deteriorate, trace this to insufficient physical training. Athletes who think their performance will improve, on the other hand, seem to want to show that they have taken advantage of the situation and have got this in return for their investment. Below are statements about the performance expectations of some athletes.

A18: "I think I will lose power because I can't do weight training. There will also be losses in endurance. At least I think it would be better if I could get through this with only a little loss. I think my performance will deteriorate at first and it will take time to recover.".

A1: "I train at home and try to overcome my shortcomings. So, I don't think my performance will change".

A7: "My performance will not be negatively affected. In the end, it will improve even more, because I'm psychologically more ready. This situation worked very well for me".

\section{Conclusion.}

Most athletes caught in the COVID-19 period have been experiencing hardships of some sort due to ambiguity regarding future competitions and their sports performance then. Selfawareness and value awareness of most athletes increased, but some athletes tended to dwell on the past. Anxiety, anger, and longing were the most commonly experienced emotion among athletes. Anxiety seems to be a result of worry about both the current situation and post-situation performance and the sports environment then. Athletes often use physical and mental training to manage the pandemic situation. Afterward, they will have developed a new field of activity. Most athletes believe their performance level will decrease after the pandemic.

\section{Limitations and Recommendations.} This research was limited to qualitative research method and restricted number of elite athletes in Turkey. Studies carried out with mixed methods in the future may provide more comprehensive information.

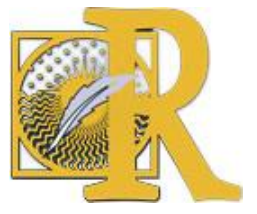

Fecha de recepción: 09-06-2020 Fecha de aceptación: 14-06-2020 


\section{References.}

- Akhtar, M. (2017). What is post traumatic growth. Duncan Baird Publishers.

- Alexander, V., \& Krane, V. (1996). Relationships among performance expectations, anxiety, and performance in collegiate volleyball players. Journal of Sport Behavior, 19(3), 246. Retrieved from: https://search.proquest.com/docview/215882631 ?accountid=11054

- Auerbach, C., \& Silverstein, L. B. (2003). Qualitative data: An introduction to coding and analysis. NYU Press.

- Bao, Y., Sun, Y., Meng, S., Shi, J., \& Lu, L. (2020). 2019-nCoV epidemic: address mental health care to empower society. The Lancet, 395(10224), 37-38. https://doi.org/10.1016/S0140-6736(20)30309-3

- Bryman, A. (2015). Social research methods. Oxford University Press.

- Chantal, Y., Guay, F., Dobreva-Martinova, T., \& Vallerand, R.J. (1996). Motivation and elite performance: An exploratory investigation with Bulgarian athletes. International Journal of Sport Psychology, 27, 173-182.

- Crabtree, B. F., \& Miller, W. L. (Eds.). (1999). Doing qualitative research. Sage Publications.

- Folkman, S., \& Lazarus, R. S. (1980). An analysis of coping in a middle-aged community sample. Journal of Health and Social Behavior, 219-239. Doi: 10.2307/2136617

- Fullagar, H. H., Skorski, S., Duffield, R., Hammes, D., Coutts, A. J., \& Meyer, T. (2015). Sleep and athletic performance: the effects of sleep loss on exercise performance, and physiological and cognitive responses to exercise. Sports Medicine, 45(2), 161-186. https://doi.org/10.1007/s40279-014-0260-0

- Hanin, Y. L. (2007). Emotions and athletic performance: Individual zones of optimal functioning model. In D. Smith \& M. Bar-Eli (Eds.), Essential Readings in Sport and Exercise Psychology (p. 55-73). Human Kinetics.

- Haug, T. T., Mykletun, A., \& Dahl, A. A. (2004). The association between anxiety, depression, and somatic symptoms in a large population: the HUNT-II study. Psychosomatic Medicine, 66(6), https://doi.org/10.1097/01.psy.0000145823.85658.0c Hsieh, H. F., \& Shannon, S. E. (2005). Three approaches to qualitative content analysis. Qualitative Health Research, 15(9), 1277-1288. https://doi.org/10.1177\%2F1049732305276687

- Kuzel, A. J. (1992). Sampling in qualitative inquiry. In B. F. Crabtree \& W. L. Miller (Eds.), Research methods for primary care, Vol. 3. Doing qualitative research (p. 31-44). Sage Publications, Inc.

- Lazarus, R. S., \& Folkman, S. (1984). Stress, appraisal, and coping. Springer Publishing Company.

- Mamassis, G., \& Doganis, G. (2004). The effects of a mental training program on juniors pre-competitive anxiety, self-confidence, and tennis performance. Journal of Applied Sport Psychology, 16(2), 118-137. https://doi.org/10.1080/10413200490437903

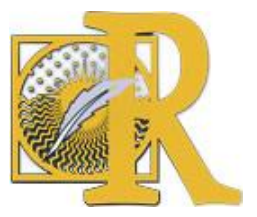


- Oettingen, G., \& Mayer, D. (2002). The motivating function of thinking about the future: expectations versus fantasies. Journal of Personality and Social Psychology, 83(5), 1198. Doi: 10.1037//0022-3514.83.5.1198

- Palmer, S., \& Cooper, C. (2013). How to deal with stress. Kogan Page Publishers.

- Pierceall, E. A., \& Keim, M. C. (2007). Stress and coping strategies among community college students. Community College Journal of Research and Practice, 31(9), 703-712. https://doi.org/10.1080/10668920600866579

- Pu, J., Hou, H., \& Ma, R. (2017). The mediating effects of self-esteem and trait anxiety mediate on the impact of locus of control on subjective well-being. Current Psychology, 36(1), 167-173. https://doi.org/10.1007/s12144-015-9397-8

- Republic of Turkey Ministry of Health (2020). Retrieved from: https://covid19bilgi.saglik.gov.tr/tr/

- Republic of Turkey Ministry of Youth and Sports (2020). Retrieved from: https://www.gsb.gov.tr/

- Richards, K., Campenni, C., \& Muse-Burke, J. (2010). Self-care and well-being in mental health professionals: The mediating effects of self-awareness and mindfulness. Journal of Mental Health Counseling, 32(3), https://doi.org/10.17744/mehc.32.3.0n31v88304423806

- Ridnour, H., \& Hammermeister, J. (2008). Spiritual well-being and its influence on athletic coping profiles. Journal of Sport Behavior, 31(1), 81-92. Retrieved from https://search.proquest.com/docview/215872291?accountid=11054

- Shi, R., Sharpe, L., \& Abbott, M. (2019). A meta-analysis of the relationship between anxiety and attentional control. Clinical Psychology Review, 72 (101754). https://doi.org/10.1016/..cpr.2019.101754

- Swann, C., Moran, A., \& Piggott, D. (2015). Defining elite athletes: Issues in the study of expert performance in sport psychology. Psychology of Sport and Exercise, 16, 3-14. https://doi.org/10.1016/i.psychsport.2014.07.004

- Taylor, S. E., Pham, L. B., Rivkin, I. D., \& Armor, D. A. (1998). Harnessing the imagination: Mental simulation, self-regulation, and coping. American Psychologist, 53(4), 429439. https://doi.org/10.1037/0003-066X.53.4.429 